\title{
AUCTION DESIGN AND THE MARKET FOR SULFUR DIOXIDE EMISSIONS
}

\author{
Paul L. Joskow
}

Richard Schmalensee

Elizabeth M. Bailey

Working Paper 5745

\author{
NATIONAL BUREAU OF ECONOMIC RESEARCH \\ 1050 Massachusetts Avenue \\ Cambridge, MA 02138 \\ September 1996
}

The authors are indebted to the MIT Center for Energy and Environmental Policy Research and to the National Acidic Precipitation Assessment Program for financial support and to the Acid Rain Division of the U.S. Environmental Protection Agency (particularly Brian McLean and Larry Montgomery) for continuing cooperation. We also thank Denny Ellerman, Richard Morgenstern, and participants in the 1996 NBER Summer Institute for useful comments. This paper is part of NBER's research program in Industrial Organization. Any opinions expressed are those of the authors and not those of the National Bureau of Economic Research.

C 1996 by Paul L. Joskow, Richard Schmalensee and Elizabeth M. Bailey. All rights reserved. Short sections of text, not to exceed two paragraphs, may be quoted without explicit permission provided that full credit, including $(\mathcal{C}$ notice, is given to the source. 


\title{
AUCTION DESIGN AND THE MARKET FOR SULFUR DIOXIDE EMISSIONS
}

\begin{abstract}
Title IV of the Clean Air Act Amendments of 1990 created a market for electric utility emissions of sulfur dioxide $\left(\mathrm{SO}_{2}\right)$. Recent papers have argued that flaws in the design of the auctions that are part of this market have adversely affected its performance. These papers incorrectly assume that trade can only occur at auctions, however. Our empirical analysis of the $\mathrm{SO}_{2}$ emissions market shows that the auctions have become a small part of a relatively efficient market and that the auction design problems that have attracted the most attention have had no effect on actual market prices.

Paul L. Joskow

Department of Economics

E52-373A

Massachusetts Institute of Technology

Cambridge, MA 02139

and NBER

pjoskow@mitvma.mit.edu

Elizabeth M. Bailey

Department of Economics

Massachusetts Institute of Technology

Cambridge, MA 02139

Richard Schmalensee

Department of Economics

E52-456

Massachusetts Institute of Technology

Cambridge, MA 02139

and NBER

rschmal@sloan.mit.edu
\end{abstract}




\section{Introduction}

Title IV of the Clean Air Act Amendments of 1990 (CAAA) created a tradable emissions allowance system to control emissions of sulfur dioxide $\left(\mathrm{SO}_{2}\right)$ produced when coal and oil are burned in electric utility boilers. ${ }^{1} \mathrm{SO}_{2}$ is the primary precursor of acid rain and other acidic depositions, and the $\mathrm{SO}_{2}$ emissions control policy provided for by Title IV was designed specifically to effect a substantial reduction in those depositions. ${ }^{2}$ The program relies on a marketbased approach to controlling emissions, rather than the traditional command-and-control approach of specifying source-specific standards. ${ }^{3}$ This mechanism involves the specification of de facto property rights for emissions that can be freely traded, and it gives electric utilities complete flexibility in determining how they will comply with their obligations under the law. Largely because it relies on an innovative market-based mechanism for controlling emissions, the $\mathrm{SO}_{2}$ allowance trading program has attracted considerable interest.

This paper examines how the market for $\mathrm{SO}_{2}$ allowances has evolved since Title IV was passed in 1990 and evaluates criticisms of the allowance trading institutions created by Title IV that have been advanced by Cason (1993, 1995), Cason and Plott (1996), and Hausker (1992). These critiques are based on theoretical analysis and experimental evidence which deal with auctions

\footnotetext{
I The 1990 CAAA is Public Law 101-549.

${ }^{2}$ The asserted target was a 10 million ton per year (about 50\%) reduction from 1980 emissions levels by the year 2000 .

${ }^{3}$ High ambient concentrations of $\mathrm{SO}_{2}$ have long been thought to have adverse effects on human health, and National Ambient Air Quality Standards (NAAQS) for gaseous $\mathrm{SO}_{2}$ have been in effect since the early 1970s. Ambient concentrations have declined significantly since that time because of state and federal command-and-control regulation, and most of the population now lives in areas that meet the NAAQS for $\mathrm{SO}_{2}$. Recent work has suggested that acid aerosols, to which $\mathrm{SO}_{2}$ emissions give rise, have significant adverse health effects, but no regulatory program currently addresses this issue directly. See, generally, EPA (1995).
} 
operating in isolation; other opportunities to trade are assumed away. Cason (1993, p. 178-179) recognizes the issue:

"The EPA auction will interact with other private markets that may be developed for permit trading....and that with sufficient activity they can help mitigate the negative features of the EPA auction. We view the interaction of these different market institutions as an open empirical question that can only be resolved after observing several years of organized trading...."

Our analysis heeds this counsel and relies on the considerable information now available on actual transactions (as well as offers to buy and sell) in the market for $\mathrm{SO}_{2}$ allowances. Overall, we find that the design flaws emphasized by the critics have not had significant adverse effects on market performance, largely because the market institutions on which the critics have focused have not played -- and were never intended to play -- central roles in the actual trading process. ${ }^{4}$

Although $\mathrm{SO}_{2}$ emissions control obligations of the first group of electricity generators affected by Title IV did not take effect until 1995, the first allowance trades were reported in May, 1992. There are two very different venues in which allowance trading takes place. As we discuss in more detail below, the vast majority of allowance trading has involved bilateral private trades between utilities that own electric generators or between those utilities and third parties. ${ }^{5}$ The third parties include allowance brokers, acting for their own account or on behalf of electricity generators, as well as fuel suppliers who bundle the sales of allowances with the sale of fuel to

\footnotetext{
${ }^{4}$ The flaws in the auction design could be more empirically important if the EPA auctions were the only way that allowances could be traded. Thus we are not arguing that the auction design issues that have been raised would not be significant in other contexts. Similarly, we are not arguing that other auction designs might not have done more to hasten the development of the overall market.

${ }^{5}$ We exclude from this discussion (and from Table 1 below) "intra-utility" trades, such as reallocations of allowances between generating units owned by the same company and transactions between affiliates of the same holding company.
} 
electric utilities. Although these transactions are generally confidential, some information on individual transactions is available in the trade press. More importantly, there are three major private market-making organizations that regularly publish information on allowance prices in consummated transactions as well as on bids to buy and offers to sell. The information published by these market-makers can be used to define "the market price" for allowances at any particular point in time.

The second way that allowances have been traded is through a set of annual auctions that Section 416(d)(2) of the CAAA requires the Environmental Protection Agency (EPA) to hold. The auctions were first held in March 1993 and have taken place every March since then. As this is written, we have data on four years of auctions, covering a total of eleven separate auctions.

The structure of these auctions has been criticized by Cason $(1993,1995)$, Cason and Plott (1996), and Hausker (1992). As we shall discuss below, the positive conclusions reached in these papers are, at best, only weakly consistent with the data. This seems to reflect the fact that the EPA auctions have been only a small part of the overall allowance market, while Cason $(1993,1995)$ and Cason and Plott (1996), in particular, proceed as if the auctions were the whole market. For the same reason, the critics substantially over-state the potential adverse effects of defects in auction design on overall market efficiency. With the possible exception of the initial EPA auctions, which took place as the private market was just beginning to develop, the EPA auctions that have attracted so much attention in the academic literature have been of minimal relevance for the overall performance of the market. Auction prices and associated bidding behavior and private market prices are now closely linked with one another. 
The paper proceeds in the following way. The next section provides a brief discussion of Title IV of the CAAA, the associated allowance trading system, and how it is being phased in. Section 3 outlines the critiques referred to above. Section 4 examines the time patterns of allowance prices that have been observed so far, drawing on observation of both private market transactions and the EPA's annual auctions. Section 5 examines the auction results in more detail and compares them with the predictions drawn by critics from previous theoretical analyses and laboratory experiments. Section 6 presents our conclusions.

\section{Title IV and Allowance Trading}

The basic approach to emissions control embodied in Title IV is simple. Aggregate annual caps on national $\mathrm{SO}_{2}$ emissions from certain electric generating units are specified by the statute. These caps define the number of emissions allowances issued for use in each year. An emissions allowance is the right to emit one ton of $\mathrm{SO}_{2}$ into the atmosphere. In order legally to emit $\mathrm{SO}_{2}$ into the atmosphere during a particular year, an electricity generator covered by the statute (called an "affected source" in the Act) must have enough allowances that are good for use in that year to cover all of its emissions. The CAAA requires each affected source to have continuous emissions monitoring equipment on each stack to measure actual $\mathrm{SO}_{2}$ emissions and to report those emissions to the EPA. At the end of each year, each source must have deposited enough allowances in an account maintained for it by the EPA to cover all of the recorded emissions or be subject to significant financial (and legal) penalties.

The restrictions on $\mathrm{SO}_{2}$ emissions are applied in two phases. Phase I covers the 263 dirtiest large generating units in the country and requires them, in the aggregate, to reduce their emissions 
substantially, to about 5.7 million tons per year, during the period $1995-1999{ }^{6}$ Phase II, which begins in 2000 , tightens the emissions cap further and extends it to virtually all electric generating units. About 9 million allowances will be issued annually during Phase II.

Title IV also specifies the initial allocation of $\mathrm{SO}_{2}$ allowances. Allowances are given to existing electric generating units and those under construction according to fairly complicated rules that are discussed in detail by Joskow and Schmalensee (1996). For our purposes here it suffices to note that essentially all of the allowances available to cover $\mathrm{SO}_{2}$ emissions were allocated "free" to incumbent sources. Each allowance specifies a particular year, its "vintage," in which it is first available to be used to cover $\mathrm{SO}_{2}$ emissions; an allowance can also be "banked" and used in any future year. Thus, for instance, a "1996 vintage" allowance can be used to cover emissions in 1996 or held for use in any later year, but it cannot be used to cover 1995 emissions. Most importantly, all allowances are fully tradable. That is, a source that has been allocated allowances is free to sell them to any other source, including to a third party such as brokers and individuals. Moreover, an affected source can buy allowances to cover its present emissions or its future emissions from any type of trading partner. There are no limitations on how often parties can trade allowances or on the trading mechanisms that buyers and sellers may use to trade them.

Finally, Title IV created two mechanisms intended to help "jump-start" the market. The more important is a set of small annual revenue neutral allowance auctions that are administered by the EPA. Each year, roughly $2.8 \%$ of the allowances that have been allocated to utilities are held

\footnotetext{
${ }^{6}$ In fact, an additional 182 generating units that were not otherwise due to become "affected sources" until Phase II became affected in Phase I through special (substitution unit or compensating unit) provisions of a compliance plan for one or more of the original 263 Phase I units. See EPA (1996) for statistics and Joskow and Schmalensee (1996) for summaries of these provisions.
} 
back and auctioned in annual "spot" and "advance" auctions. In the 1993, 1994, and 1995 spot auctions, 50,000 vintage 1995 allowances were offered for sale. In 1996, 150,000 vintage 1996 allowances were sold. In 1997, 1998, and 1999, 150,000 allowances with vintages matching each of those years will also be sold. In 2000 and later years, 100,000 allowances will be sold in the annual spot auction. In 1993 and all later years, 100,000 allowances are offered for sale in the seven-year advance auction. Allowances sold in the advance auction are first usable seven years after the auction. Thus, vintage 2000 allowances were sold in 1993, vintage 2001 allowances in 1994, and so on. The revenues from these sales are returned to the sources in proportion to their share of the allowances that were held back for the auctions. In addition, private parties are permitted but not required to offer allowances for sale in either EPA auction. ${ }^{7}$ Each voluntary offer to sell allowances in the EPA auctions involves both a quantity and a minimum acceptable (i.e., reservation) price.

Much attention has been paid to the specific auction mechanism that was implemented by the EPA's regulations. Title IV [Section 416(d)(2)] provides that:

"...the auctioned allowances shall be allocated and sold on the basis of bid price, starting with the highest-priced bid and continuing until all allowances for sale at auction have been allocated."

The EPA has thus far interpreted this statutory language as requiring it to implement a "discriminatory" auction in which the allowances withheld for auction by the EPA are allocated to the highest bidders and the winning bidders must pay the price they have bid rather than a uniform

\footnotetext{
${ }^{7}$ Allowances may also be voluntarily offered for sale in the six-year advance auction described below. There are no restrictions on sales of allowances outside of the EPA auctions.
} 
market clearing price. ${ }^{8} \quad$ Allowances submitted voluntarily by private parties for sale in the EPA auction are allocated after the supply of withheld allowances have been fully allocated. At that point, the seller with the lowest reservation price is matched with the remaining buyer with the highest bid, the seller with the second lowest reservation price is matched with the remaining buyer with the second highest bid, etc., until there are no more bids to buy that exceed the reservation prices submitted by sellers. ${ }^{9}$ When private allowances are sold in this way, the seller receives the buyer's bid price.

In addition to the annual auctions, 25,000 allowances per year are allocated to a "Direct Sales Reserve" beginning in 1993. These allowances are available for purchase at a price of $\$ 1,500$, adjusted for post-1990 inflation; they are first valid seven years from the date they are made available for purchase. Beginning in the year 2000, the Reserve also makes 25,000 spot allowances per year available for purchase at $\$ 1,500$ (adjusted for post-1990 inflation). In the event the Reserve is over-subscribed, the statute gives preference to independent power producers constructing new capacity. In the event some allowances in the Reserve are not purchased within a year, the remaining allowances are auctioned in a separate "six-year advance" auction in the following year at the same time the other two auctions take place. Thus, for instance, the 1993 Reserve made available vintage 2000 allowances for $\$ 1500$ each. As none were sold by the time of the 1994 auctions, 25,000 vintage 2000 allowances were auctioned in a 1994 six-year advance auction. Since allowance prices have always been far below $\$ 1500$, all of the allowances made

\footnotetext{
${ }^{8}$ The EPA has recently solicited comments on whether it has the statutory authority to switch to single-price auctions and whether such a switch would be desirable, as well as on whether it would be desirable to move the auctions from March to October of each year. See Federal Register, June 6, 1996 (Volume 61, Number 110), pp. 28996-28997.

${ }^{9}$ Note that this amounts to selling the allowances withheld by the EPA at a reservation price of zero.
} 
available in the Direct Sales Reserve have so far been auctioned off in the subsequent year. Section 416(c)(7) requires EPA to terminate this program if it is under-subscribed, and add the allowances from the Direct Sales Reserve to the annual advance auctions. EPA has recently announced its intention to do this after the 1996 set-aside. $^{10}$

It is important to understand that these mechanisms do not determine the initial allocation of allowances, nor do they represent the only market mechanism through which sales and purchases of allowances take place. Buyers and sellers can employ any trading arrangement they choose, and intermediaries are free to establish any brokerage, auction or trading mechanism that they wish. Indeed the initial version of Title IV as proposed by the Bush Administration did not contain provisions either for the mandatory EPA auctions or the Direct Sales Reserve. These provisions were added to the bill as it worked its way through Congress in response to concerns raised by independent power producers and utilities in rapidly-growing states that market imperfections, which might include irrational hoarding by utilities or anti-market behavior by state public utility regulators, ${ }^{11}$ might make it impossible for them to acquire the allowances necessary to construct and operate new generating capacity. The auctions were intended to start the market by effectively forcing trades, while the Direct Sales Reserve was intended to provide some measure of insurance against major market failure. It was the intention of the Bush Administration, the proponents of the legislation in Congress, and the EPA in drafting the regulations implementing the CAAA that

\footnotetext{
${ }^{10}$ Federal Register, June 6, 1996 (Volume 61, Number 110), pp. 28761-28763. Section 416(f) allows EPA to terminate the annual auction, but only if less than $20 \%$ of withheld allowances are unsold for two years in a row. Since these allowances are offered with zero reservation prices, as noted above, this is extremely unlikely to occur.

${ }^{11}$ As Fullerton, McDermott, and Caulkins (1996) argue, the potential cost-increasing impact of state regulatory behavior could be substantial. Bailey (1996) finds, however, that regulators have in fact generally accommodated utilities with interests in trading.
} 
private trading arrangements, not the EPA auctions, would be the primary mechanisms through which allowances would be traded. Accordingly, neither the CAAA nor the regulations implementing it place any restrictions on the kinds of bilateral arrangements, brokering, and private auction institutions that private parties can turn to in order to mediate allowance trades.

\section{Critiques of Allowance Trading Institutions}

Even though the annual statutory auctions were designed primarily to "jump-start" the market, not to be the primary venue for trading allowances, they have attracted a significant amount of attention and criticism in the literature. Indeed, one would think from the discussion in the literature that the EPA auctions are the main, or even the only, mechanism through which allowances can be traded.

Hausker (1992) provides an illuminating discussion of the origins of the auction design specified in Section 416. He describes this design as a triumph of House staff, representing the interests of Midwestern states likely to be substantial net sellers of allowances, over Senate staff, without ties to states with major interests in Title IV. He argues that House staff were primarily concerned with maximizing seller revenue, while the Senate staff were free to focus on market efficiency.

Senate staff proposed that multi-year streams of allowances be auctioned off to facilitate planning for new capacity. (Such a stream might consist of 100 allowances each of vintages 1995 , $1996, \ldots, 2015$, for instance.) House staff, on the other hand, sought to provoke a "feeding frenzy" by forcing those who wanted to acquire at auction the allowances needed for the life of a new plant to buy large quantities of single-vintage allowances. The Bush Administration generally sided with 
the simpler House design, which prevailed. ${ }^{12}$ The Administration's view was that if the market developed properly, the Senate regime would represent an unnecessary intrusion into the private trading process, while the "feeding frenzy" sought by the House would not materialize because of the existence of private sources of supply. If the market did not develop properly, the Senate scheme would not help much. In fact, since buyers and sellers clearly had interests in trading streams of allowances, one could argue that excluding streams from the EPA auctions hastened the development of useful private market institutions.

Similarly, Hausker notes that the idea of having a discriminatory auction came from House staff. As he observes, it is not clear in theory that this design will produce more revenue than a uniform-price auction, though the House staff were unshakably convinced that it would. ${ }^{13}$ Senate staff and the Administration preferred a single-price auction. Both were concemed that a discriminatory auction would be a less transparent price discovery mechanism, and the Administration argued that a discriminatory auction would likely discourage participation by regulated utilities and/or lead them to under-bid. ${ }^{14}$ Nonetheless, Administration economists did not consider this a major issue. Their view was that if there were no serious obstacles preventing the development of an allowance market, a discriminatory auction could, at worst, slow that development somewhat, while if there were serious obstacles, fixing the auction design would not suffice to create a viable market.

\footnotetext{
${ }^{12}$ The second author participated in Administration policy-making on this issue.

${ }^{13}$ The second author spent hours trying unsuccessfully to persuade the House staff involved that buyers would not simply bid their reservation prices in this auction. He was accused of not understanding basic economics. For a recent discussion of the relevant theoretical and empirical literature, see Laffont (1995), pp. 24-25.

${ }^{14}$ The problem is that state utility regulators can disallow utility costs that they find to have been "imprudently" incurred, and if utility A pays more for allowances than utility B at the same auction, A becomes potentially vulnerable to such a finding. This potential vulnerability can only discourage aggressive bidding.
} 
Cason (1993, 1995) and Cason and Plott (1996) argue that voluntary sellers in the EPA auctions have incentives to set reservation prices too low. Cason $(1993,1995)$ models sellers as engaged in a private value auction: The gain from sales of an allowance at the auction equals the price less the seller's individual marginal cost of reducing $\mathrm{SO}_{2}$ emissions by a ton. The central argument is that in the EPA auction, lowering one's reservation price both increases the likelihood of a sale and, conditional on a sale occurring, increases the expected price received as long as buyers' bids are not identical. Thus, lower reservation prices will be set by rational sellers than in a single-price auction, all else equal. It may even be optimal to set a reservation price below the marginal cost of emissions reduction, even though this creates a positive probability of an unprofitable trade. Cason (1995) finds some experimental support for this downward bias in seller reservation prices. ${ }^{15}$

In addition, Cason and Plott (1996) argue informally that buyers in the EPA auctions, whose gain from purchase is assumed to be the marginal control cost avoided minus the price paid, have an incentive not to bid above the expected market-clearing price. ${ }^{16}$ While this is plausible behavior, it is not clear either that it is optimal or that by itself such bidding would tend to bias down prices. Cason and Plott (1996) find experimentally that "compared to more standard uniform-price call auctions, the EPA auction generates lower market-clearing prices and extracts less gains from exchange" (p. 157).

\footnotetext{
${ }^{15}$ Cason's (1995) paper is a little confusing at first blush because his theoretical analysis and the laboratory experiments invert the structure of the EPA's auction so that the sellers are buyers and the buyers are sellers.

${ }^{16}$ They do not offer a formal characterization of an equilibrium in the EPA auction in which both buyers and sellers behave strategically. Cason (1993) discusses some of the complexities involved.
} 
As we noted above, Cason (1993, p. 178) acknowledges that other venues for allowance trading will interact with the EPA auctions, and "should these alternative trading mechanisms develop, the additional trading opportunities will place opportunity cost bounds on the allowance values for EPA auction participants." In the extreme case, in which the outside market is perfectly competitive and without frictions, the "opportunity cost bounds" serve to transform the EPA auction into a common value auction. The universally known market price of allowances, call it $\mathrm{P}^{*}$, replaces individual marginal control costs in buyers' and sellers' strategic calculations, and the equilibrium auction price must equal $\mathrm{P}^{*}$. Given the competitive market alternative, no buyer will pay more than $\mathrm{P}^{*}$, and no seller will take less. Only if the non-auction part of the market is seriously imperfect -- or, in the limiting case assumed by Cason $(1993,1995)$ and Cason and Plott (1996), nonexistent -- can auction prices depart substantially from competitive market prices. More generally, if buyers' bids are all close to $\mathrm{P}^{*}$ (or any other number), sellers' incentives to quote low reservation prices in order to be matched with high bids will be essentially eliminated.

Cason and Plott (1996) assert that through early 1994 the allowance market did not impose tight "opportunity cost bounds" on the EPA auction, but they present only anecdotal evidence to support this assertion. In what follows we attempt a systematic examination of the evidence available through mid-1996. We find that as private trading institutions have matured, the prices and bidding behavior in the EPA auctions have become closely linked to trading opportunities in the private market. Thus, if the critics' analyses have any implications at all for the $\mathrm{SO}_{2}$ allowance market, they are likely to be relevant only to the earliest auctions, which took place early in the development of an active private market and associated trading institutions. Moreover, the 
behavior of voluntary sellers, who have had at most a trivial impact on the market, suggests overstatement, not under-statement, of reservation prices.

\section{Market Prices and Quantities}

At the time Title IV was passed a number of projections of future allowance prices were made available to the EPA and published in the trade press. These projections were based on costminimizing optimization models for the electric power sector that embodied assumptions about future fuel prices, electricity demand growth, utility trading behavior, and the costs of reducing $\mathrm{SO}_{2}$ emissions through fuel-switching, coal-cleaning, and flue-gas desulfurization (scrubbing). Allowance prices during Phase I were generally projected to be in the $\$ 250-\$ 350$ range and prices for allowances in Phase II in the $\$ 500-\$ 700$ range. ${ }^{17}$ These projections were the primary information available to buyers and sellers when allowances began to be traded, first through a few bilateral trades and then in the EPA's first set of mandatory auctions in March 1993.

In fact, prices have turned out to be much lower than those early projections. Indeed, prices for spot market Phase I allowances have gone as low as $\$ 63$ per ton and are about $\$ 80$ per ton as this is written. It seems that post-1990 developments in markets for coal from the Powder River basin in Wyoming are central to the large differences between projected and actual prices (see Ellerman and Montero (1996)). In any case, these large differences counsel humility about both the accuracy of the models available for analyzing policies of this sort and, more generally, about our

\footnotetext{
${ }^{17}$ See, for instance, ICF (1990) and Braine (1991). The large difference in price projections for Phase I and Phase II does not make a lot of economic sense, since Phase I allowances can be banked for use in Phase II. However, the models used to make these projections did not take intertemporal arbitrage opportunities into account. The $\$ 1,500$ price set for the Direct Sales Reserve was designed to be significantly above the range of price projections that were being relied upon when the CAAA was being debated.
} 
ability to estimate the cost of complying with new environmental restrictions when polluters are allowed to employ the most economical compliance strategies they can devise. While these issues are important, pursuing them further would carry us beyond the bounds of this study.

Figure 1 displays information on vintage 1995 allowance prices between May 1992, when the first bilateral trade was reported, and June 1996, the last month for which we have information. Figure 1 is based on three different types of sources. First, we have information on the prices at which some private trades took place that were reported in the trade press. By and large, however, buyers and sellers keep the details of their allowance transactions confidential, so there are few observations of this sort available to us. Moreover, we cannot verify the accuracy of the information on price or on associated terms and conditions reported in the trade press.

The second source is price information published by one or more of three private organizations that act as intermediaries between transacting parties, accept bids to buy and sell allowances, sometimes trade for their own account, and publish allowance price information for clients without identifying specific parties to the transactions. These organizations are Cantor Fitzgerald (CF), the Emission Exchange Corporation (EX), and Fieldston (EATX). The EX price index begins in July 1993, the EATX price index in June 1994, and the CF price index in August 1994. These indices are available to us only on a monthly basis, but they were available continuously to the clients of these organizations. These indices are the best information available on allowance prices associated with private trading activity. All three indices are a cash, spot market price of a 1995 vintage allowance expressed in current dollars, and each is determined from private information the organization has on recent and pending transactions, market activity from previous weeks, offers to buy and sell, and prices buyers and sellers have indicated a willingness to 
accept. Figure 1 displays the reported prices for each of these proprietary indices for vintage 1995 allowances. $^{18}$ Since August 1994 the allowance prices reported by the three organizations are almost identical.

Finally, we have extensive information reported on the EPA's annual March auctions from 1993 through 1996. This information includes bid prices and quantities submitted by each buyer, the prices at which allowances and associated quantities were offered voluntarily for sale by individual sellers, the bid price that cleared the EPA's mandatory sales auctions, and the bid price that cleared the associated voluntary private sales auction. We also have the trading names used by each of the winning bidders and the associated prices and quantities that each bid. These names usually allow a meaningful identification of the winning bidders, though some bidders trade under special "trading names" (which is perfectly legal) to maintain confidentiality. Moreover, some buyers rely on intermediaries to bid for them in the auction for the same reason. We will explore this information in more detail in the next section.

Figure 1 simply reports the market clearing price in the EPA's mandatory "spot" auction for comparison with the other information on prices for 1995 vintage allowances. We defer until the next section a discussion of the results of the voluntary sales component of the EPA's annual auction. Here we note only that few allowances have been offered for sale in the voluntary "private" portion of the EPA's annual auction, and very few of those had reservation prices low enough to be sold.

\footnotetext{
${ }^{18}$ As noted above, the 1995 vintage is the first vintage of allowances that exists since that is the year Phase I begins. A substantial number of 1995 vintage allowances were not used to cover emissions in 1995 because emissions were below the cap. These allowances were banked and are available to cover emissions in 1996 or any future year. Thus, in 1996 the remaining 1995 vintage allowances are perfect substitutes for 1996 vintage allowances. It is the latter that were auctioned in the EPA's March 1996 spot auction.
} 
Reports of electric utilities and financial intermediaries actively seeking buyers and sellers for $\mathrm{SO}_{2}$ allowances appeared in the trade press as early as $1991 .{ }^{19}$ The first bilateral trades appeared in the press in May and July 1992. ${ }^{20}$ The first announced trade was a sale of 10,000 allowances (vintage information was not revealed) by Wisconsin Power and Light Company to the Tennessee Valley Authority at $\$ 265$ per allowance. ${ }^{21} \quad$ The second was a purchase of 25,000 allowances by Ohio Edison from the ALCOA Corporation, a joint owner of a Phase 1 affected plant, for $\$ 300$ per allowance. Allowance prices in both of the first two trades were close to initial estimates of Phase I allowance prices referred to above. No additional information on prices in private transactions appeared before the EPA's first auction in March 1993, although trade press reports indicated that other bilateral trading activity was taking place.

The market-clearing price in the March 1993 spot auction was $\$ 131$ and the market clearing price in the 1993 advance auction (for vintage 2000 allowances) was $\$ 122$. Trade press reports at the time suggested that utilities and intermediaries were surprised by the low prices that emerged in the auction and generally that "the auction had more participants and sold more allowances at lower prices than expected."22 One utility executive characterized his company's purchase of 10,000 allowances at $\$ 150$ per allowance in the 1993 spot auction as "quite a bargain." 23

\footnotetext{
${ }^{19}$ Energy Daily. May 15, 1991.

${ }^{20}$ Early reports of trades can be found in the Wall Street Journal (May 11, 1992 and July 1, 1992), the New York Times (May 11, 1992), Energy Daily (May 13, 1992 and July 1, 1992) and various issues of Compliance Strategy Review.

${ }^{21}$ At the same time as the TVA trade, Wisconsin Power and Light announced it sold 15,000 allowances to Duquesne Light Company. Both parties declined to release information on vintage(s), price, and other terms of trade. Duquesne even declined to confirm the number of allowances it had purchased.

${ }^{22}$ Electric Power and Light. May 1993. p1.

${ }^{23}$ Ibid. p3.
} 
In mid-1993, the trade press reported price data on two additional private transactions at $\$ 178$ and $\$ 205^{24}$ At about the same time EX began to report information on vintage 1995 allowance prices gathered confidentially from private parties. The first reported price was $\$ 170$. The EX price remained at, or slightly above, the $\$ 170$ per ton level until May 1994. In November 1993, a trade press report identified another private trade at $\$ 205,{ }^{25}$ significantly above both the EX price and the earlier auction price. This is our last trade observation for a specific bilateral transaction. Clearly, up through the end of 1993 it would have been difficult to define a clear uniform market price from the information then available, as recent transactions were all over the map.

The EPA's second auction took place in March 1994. The spot auction price that cleared the market was $\$ 150$ and the immediate settlement prices were $\$ 140$ for vintage 2000 allowances (25,000 allowances left over from the previous year's Direct Sales Reserve) and $\$ 140$ for vintage 2001 allowances. The auction prices were higher than the 1993 auction prices, a bit more than 10\% lower than the prevailing EX prices, and still far below earlier projections of Phase I allowance prices.

In mid-1994, following the EPA's second auction, EATX and then CF begin to publish information on allowance prices associated with confidential private transactions and offers to buy

\footnotetext{
${ }^{24}$ Compliance Strategy Review (June 21, 1993 and July 19, 1993) reports that Big Rivers Electric Cooperative engaged in two sales of allowances of undisclosed vintages. In June, Big Rivers sold 150,000 allowances to Centre Financial at $\$ 178$ per allowance, and in July, sold 4,384 allowances to American Municipal Power at $\$ 205$ per allowance. Unlike earlier allowance trades, these and most future allowance transactions, go unnoticed in the national press.

${ }^{25}$ Compliance Strategy Review (November 8, 1993) reports that Wisconsin Electric Power Company sold 37,000 allowances of an undisclosed vintage to PSI Energy at a price of \$205 per ton for allowances received in 1995 . Terms of the trade released indicate that the allowances were to be supplied by Wisconsin Electric Power Company over an 8 year period beginning in 1995 , and that the price, $\$ 205$ per ton, is to be escalated over the remainder of the contract at an undisclosed rate.
} 
and sell. As is evident from Figure 1, the prices reported by the three organizations for allowances sold and offered for sale or purchase in the private market were almost identical by late 1994 . Moreover, the March 1995 and March 1996 EPA auctions yielded market clearing prices that were virtually identical to the prices reported for the three price indices. (We can't match the prices precisely because we only have monthly observation for the three private market indices).

Let us now turn from prices to quantities. Table 1 reports information on the number of allowances that appear to have been traded through both the EPA's auctions and in private transactions through the first quarter of 1996 . The first column reports the total number of allowances, withheld and privately offered, sold in each of the EPA's annual auctions. In total, fewer than 800,000 allowances have been traded through the EPA's mandatory and voluntary private auctions. The volume of private market transactions is more difficult to determine since there is no source that reports the precise quantity of allowances covered by purchase and sale agreements. We have made use of the data contained in the EPA's allowance tracking system to make a lower bound estimate of the volume of trades that took place during various time periods between 1992 when the first trades took place and the latest EPA auction in March 1996. To understand how we have made these estimates we must explain briefly how the EPA's allowance tracking system works.

The EPA established a computerized allowance tracking system to keep track of allowance allocations, to record reallocations of allowances between generating units over time (via banking), and to match emissions from a specific source in each year with the allowances it possesses. Initially, all generating units that were allocated allowances through the statutory provisions of Title IV were given an individual allowance account in the EPA's computer system. Their allocations of 
allowances for each future year (through the year 2025) were placed in these accounts. Third parties that are involved in trading allowances can also establish accounts in the EPA's allowance tracking system, and those that bid in the EPA auctions must establish such accounts to receive any allowances that they may purchase through the auctions.

At the end of each year, each affected generating unit must have enough allowances of appropriate vintages (the current year's vintage or earlier) in its account to cover its emissions for that year. Utilities that own multiple generating units may shift allowances between accounts to cover their emissions. When allowances are bought or sold through private transactions, the trades must eventually be recorded in the EPA's allowance tracking system in order for the allowances to be used to cover emissions, but parties are under no obligation to record private trades with the EPA within any particular period after they have been consummated. (The EPA automatically records allowances traded in its annual auctions as soon as the results from the auction are made publicly available.) Our understanding is that prompt recording of private trades is the rule rather than the exception, however. ${ }^{26}$ Nonetheless, since there is no doubt some lag between the time a deal is struck and the time allowances are moved between accounts in the EPA's allowance tracking system, the recorded data must lag behind actual commercial transactions to some extent. ${ }^{27}$

We have accessed the EPA's allowance tracking system to identify commercial trades based on the recorded movement of allowances between accounts. We first identified all movements of

\footnotetext{
${ }^{26}$ Telephone interview with Eugene Casey, Acid Rain Division, U.S. Environmental Protection Agency, June 1996.

${ }^{27}$ To record an allowance transfer with EPA, the parties have had to submit a form signed by authorized representatives of both accounts involved, and EPA has undertaken to record the transfer within five business days. To speed up this process, EPA has recently announced that it is considering the development of a system to allow electronic submittal of allowance transfers. See Federal Register, June 6, 1996 (Volume 61, Number 110), pp. 28996-28997.
} 
allowances between accounts. We then deducted allowances that were associated with special EPA allocations (e.g. bonus allowances made available for scrubbers; see Joskow and Schmalensee (1996)), EPA auctions, reallocations, and intra-utility trades to identify all changes in allowance allocations between unaffiliated entities. We believe that this provides a good lower bound estimate of private allowance transactions because it measures all private trades that the parties have chosen to record in the EPA's allowance tracking system. It may not measure all private trading activity, because there is no obligation to record trades for allowances until the holder desires to use the allowances for compliance purposes. In addition, this number represents a lower bound estimate of private trading activity since any trading pursuant to option agreements would not be recorded until options are actually exercised. ${ }^{28}$

The second column of data in Table 1 reports private allowance trades that were recorded in the year proceeding each of the EPA's auctions, including the month of the auction, except for the first auction for which the period covers all private trades (as defined above) recorded by EPA before the auction took place. All together, by March 1996 about 6.7 million allowances were traded through private transactions, as compared to 0.8 million through the EPA auctions. ${ }^{29}$ It is also evident from Table 1 that there was very little private trading activity prior to the second quarter of 1994 . About 6.4 of the 6.7 million allowances that were privately traded up through March 1996 were traded after March 1994.

\footnotetext{
${ }^{28}$ In June 1993, Compliance Strategies Review reported that AMAX Energy purchased from Long Island Lighting Company an option to purchase Phase I allowances (quantity and prices were not disclosed). To date this option has not been exercised and consequently this trading activity does not show up in the EPA's allowance tracking system.

${ }^{29}$ Only 4.3 percent of the 6.7 million privately traded allowances through the end of March 1996 represent nonutility to non-utility transactions.
} 
Figure 1 and Table 1 suggest that in the early stages of the development of the allowance market, buyers and sellers had little information about market-clearing allowance prices. Initial transactions prices appear to have been influenced by earlier allowance price projections. The first two EPA auctions represented just under half (48\%) of the allowance trading activity occurring as of those dates, and helped to establish visible market values. Looking at Figure 1, one could argue that the data through May 1994 are consistent with the sort of downward bias in EPA auction prices stressed by Cason $(1993,1995)$ and Cason and Plott (1996). As we discuss in more detail below, however, almost no privately-offered allowances were sold in the first two EPA auctions, so that the seller-side bias stressed by Cason $(1993,1995)$ can have had no effect. Any downward bias must reflect a bias in buyers' bids, for which the theoretical case is not strong. In any case, the coupling between the EPA auctions and the rest of the market does not appear particularly tight in the early period.

Beginning around May 1994, however, Figure 1 shows that private market prices come almost exactly into line with the results of the March 1994 EPA auction. This casts significant doubt on the downward bias hypothesis. It seems at least as plausible that non-auction prices had been held up artificially by the earlier projections of higher prices. The early auctions suggested, correctly as it turned out, that those projections were too high. These suggestions may well have deterred some investments (in scrubbers, for instance) that were attractive at projected allowance prices but would have been uneconomic at the prices prevailing in the market after mid-1994.

By the March 1995 auction, market values in all trading venues were essentially the same. In Cason's (1993) language, the "opportunity cost bounds" placed on auction participants by "additional trading opportunities" had plainly become tight. As uncertainty about allowance 
market values at a particular point in time were resolved, trading activity increased enormously. To the extent that the auctions brought parties to the market and helped to establish a range of market valuations, they fulfilled their primary objective of stimulating the development of private market trading activity of all kinds. Other auction designs might have performed this function better, of course, but it seems clear that the EPA auctions did perform it.

\section{Results of the EPA Auctions}

Figures 2-5 present detailed results for each of EPA's auctions, using a format similar to those typically employed to report laboratory experiments. We construct a stairstep buyers' offer curve by drawing, at a height corresponding to each bid price, a horizontal line with length corresponding the associated bid quantity. The buyers' offer curve is constructed by joining these lines end-to-end, starting with the highest bid price and working down to the lowest. On the supply side of the market, the number of allowances offered for sale in the mandatory (as required by Title IV) auction is represented by a vertical line at the relevant quantity on the horizontal axis. We complete the sellers' offer curve to include voluntary offers to sell allowances by drawing horizontal lines at heights corresponding to the associated reservation prices and with lengths corresponding to the quantities voluntarily offered at those prices. These are joined to the top of the vertical line just discussed, beginning with the lowest reservation price and working up to the highest, since voluntary offers to sell do not get matched with buyers' offers to buy until the EPA's mandatory sales offering is fully subscribed. The intersection of the buyers' offer curve and the sellers' offer curve defines the market clearing price; it is the price of the lowest bid at which allowances were purchased. 
Figure 2 displays the results for the 1993 spot and advance auctions. Figures 3, 4, and 5 display the results for the spot and the two advance auctions conducted in 1994, 1995 and 1996 respectively. The dots on each figure represent bid prices and associated quantities. Note that there are frequently a number of dots that appear to be on the vertical axis. These are bids for very small numbers of allowances (often one allowance) submitted by individuals, environmental groups, law schools, and other organizations. For example, in the 1993 advance auction (Figure 2b) Resources for the Future bid $\$ 310$ for one allowance, when the market clearing price was $\$ 122$. Student environmental groups at law schools were the eight highest bidders (for one allowance in seven of the cases and five allowances in the other case) in the 1995 spot auction (Table 4a) paying between $\$ 150$ and $\$ 350$ per allowance when the market clearing price was $\$ 130$.

Figures $2 \mathrm{a}$ and $2 \mathrm{~b}$ show that the buyers' offer curves have considerable dispersion in both the spot and advance auctions held in March 1993. Thus a significant volume of the allowances sold traded at prices significantly higher than the market clearing price. A significant number of "low ball" bids at very low prices are also observed. Since there is no fee required to submit a bid and minimal requirements to do so, there is little to lose from submitting a low bid, especially in 1993 when there was relatively little information available to predict the market-clearing price for allowances.

Figures $3 a, 3 b$, and $3 c$ report the results for the second set of EPA auctions, which occurred in March 1994. It is evident that the 1994 buyers' offer curves are much flatter than those for 1993 and that the number of allowance sales that took place at prices significantly higher than the market clearing price declined considerably. The few bids to buy at prices far above the clearing price are from individuals or groups typically purchasing one allowance for non-commercial reasons. The 
change from Figures 2 to Figures 3 is consistent with the discussion in the previous section: The development of the outside market significantly tightened the "opportunity cost bounds" on the behavior of auction participants.

Finally, Figures 4 and 5 report the auction results for 1995 and 1996 respectively. The buyers' offer curves now become quite flat and few allowances are traded at prices much above the market clearing price. A few individual buyers continue to pay high prices, but these are clearly not standard commercial transactions that have any implications for $\mathrm{SO}_{2}$ emissions mitigation. These are novelty purchases or purchases by groups attempting to make a statement. If one wants to purchase a small quantity of allowances for whatever reason, the EPA's auction is the place to do so because utilities and intermediaries will not deal in such small quantities. The fact that some environmental groups and law student associations bid such high prices once abundant information about prices have become available suggests that they were either uninformed about the state of the market, or were so eager to obtain an allowance that they bid a price high enough to ensure that they would get one, or that they attached some positive value to purchase at a high price.

Table 2 provides some numerical evidence on the behavior of successful bidders in the EPA auctions. The Table shows the percentage difference between the average price paid and the lowest price paid (the market-clearing price) in each auction. As we noted above, if the private market were frictionless and perfectly competitive, all serious commercial bidders in the EPA auctions would simply bid the market price. The smaller the differences shown in Table 2 , the more closely buyer behavior in the EPA auction conforms to this ideal. Consistent with the discussion so far, it would be hard to argue that bidders in the 1993 auctions had a good idea of the market-clearing price. It would be a good deal easier to make this argument for the 1994 auctions, despite the 
paucity of trades before March 1994. In the 1995 and 1996 auctions, it seems clear that the frictionless, perfectly competitive ideal is a good approximation to reality, despite the continued presence of a few non-commercial high bidders.

At the other end of the price spectrum, while by 1995 the very "low ball" bids that would clearly be out of the money have largely disappeared, there continues to remain a long tail of offers to buy at prices that are up to around $10 \%$ below the best available information about market prices. Putting in bids slightly below expected market price makes perfectly good sense for a regulated electric utility seeking to purchase allowances. First, the price that will clear the market is not known with certainty and, in an auction with essentially no transactions costs, there is nothing to lose by throwing in bids at prices slightly lower than those being quoted in the private market, especially since there are likely to be transactions costs associated with substitutable private market sales. If the buyer gets nothing in the annual EPA auction and needs allowances, the private market will be open for business the next day and every day thereafter, so there are no opportunity costs associated with putting in a low bid. This, of course, would not be the case if the EPA's auction were the only way to acquire allowances. Second, regulated electric utilities may prefer to acquire allowances through confidential private market transactions that provide flexibility to arrange the ideal portfolio of allowance quantities and vintages rather than through the EPA auction. However, the prices the utility negotiates may be subject to scrutiny by their state regulatory commissions. By submitting bids to the EPA auctions at prices slightly below the prevailing private market values, the utility has a response to the regulator's question "How do we know that you paid the lowest reasonable price for the allowances?" 
Finally, let us turn to the offers to sell allowances through the voluntary "private" sellers component of the EPA's auction on which Cason $(1993,1995)$ and Cason and Plott (1996) focus. Table 3 summarizes the relevant statistics from Figures 2-5. Particularly after 1994, relatively few allowances were voluntarily offered for sale in the EPA auctions. Those allowances that were offered for sale were typically offered at prices significantly higher than the market-clearing price. As a result, less than one percent of the allowances offered were sold, and only about a third of a percent of the allowances sold in the EPA auctions were voluntarily offered (as opposed to the allowances withheld by law by EPA). In all, only 2,610 allowances have been sold using the private seller mechanism out of almost 780,000 that have been sold in EPA auctions and almost 7.5 million that have been traded overall.

This suggests that rather than reservation prices of voluntarily offered allowances being under-stated in the EPA auctions, the possibility that concerns Cason $(1993,1995)$ and Cason and Plott (1996), reservation prices are in fact over-stated relative to the alternative of private sales. The evidence on buyer behavior in Table 2 makes it clear that this pattern cannot be explained by a lack of information in the market. The most plausible explanation seems to be that some utilities use the EPA auction process to demonstrate to regulators that they could not sell their allowances at prices above those prevailing in the private market. In addition, as we noted above in connection with the persistence of "low-ball" bids, there is no cost to offer to sell at a high reservation price. Such a sale would be found money to the utility.

Most importantly, Table 3 makes clear that, if the EPA auctions have become a sideshow to the private allowance market, the private sale component of those auctions has always been a very minor act in that sideshow. However serious the flaws in the auctions' provisions for voluntary 
allowance sales, they clearly cannot have had a discernible effect on the performance of the allowance market as a whole.

\section{Summary and Conclusions}

It was clear to its proponents that the success of Title IV's innovative tradable allowance program for reducing sulfur dioxide emissions depended critically on the emergence of an effective private allowance market. At the insistence of some affected interests concerned that a robust market would not develop, an EPA-administered allowance auction and a provision for direct allowance sales at a high price were added to Title IV. Critics have pointed to apparent shortcomings in these mechanisms, particularly in the design of the annual allowance auctions that EPA is required to hold.

Our analysis of actual experience in the sulfur dioxide allowance market indicates that an effective private market has in fact developed. While it is impossible to say if an alternate auction mechanism would have hastened that development noticeably, it is clear that since mid-1994, the EPA auctions have been driven by the private market rather than vice versa. It does not appear that the aspects of those auctions that have attracted critical academic attention have had any effect at all on the actual operation of the market for $\mathrm{SO}_{2}$ allowances in recent years. And it seems absolutely clear that the incentive for strategic seller behavior advanced by Cason $(1993,1995)$ and Cason and Plott (1996) has exerted absolutely no downward pressure on allowance prices in the real world.

While the EPA auction design might very well have led to substantial inefficiencies if the auctions were the only venue for allowance trading, the fact that buyers and sellers have relied primarily on other trading mechanisms has made the EPA auctions largely irrelevant to market 
performance. Similarly, while other auction designs might have lead to more rapid development of the allowance market as a whole, the fact is that a relatively efficient market has developed in a few years' time. 


\section{REFERENCES}

Allen, Frank Edward (1992). "Tennessee Valley Authority Is Buying Pollution Rights From Wisconsin Power." Wall Street Journal, May 11, p. A12.

Bailey, Elizabeth M. (1996). “Allowance Trading Activity and State Regulatory Rulings:

Evidence From the U.S. Acid Rain Program." MIT Center for Energy and Environmental Policy Research, MIT-CEEPR 96-002 WP, March.

Braine, Bruce H. (1991). “Allowance Market Implications of Acid Rain Regulation.” Pp. 88-105 in R. Locke and D. P. Harkawik, eds., The New Clean Air Act: Compliance and Opportunity. Arlington, VA: Public Utilities Reports.

Cason, Timothy N. (1993). "Seller Incentive Properties of EPA's Emission Trading Auction." Journal of Environmental Economics and Management, 25 (September): 177-195.

Cason, Timothy N. (1995). “An Experimental Investigation of the Seller Incentives in EPA's Emission Trading Auction." American Economic Review, 85 (September): 905-922.

Cason, Timothy N., and Charles R. Plott (1996). “EPA's New Emissions Trading Mechanism: A Laboratory Evaluation." Journal of Environmental Economics and Management, 30 (March): 133-160.

Compliance Strategy Review. (selected issues, 1992-6), Fieldston Publications, Washington DC.

Ellerman, A. Denny and Juan Pablo Montero (1996). “Why Are Allowance Prices So Low? An Analysis of the $\mathrm{SO}_{2}$ Emissions Trading Program." MIT Center for Energy and Environmental Policy Research, MIT-CEEPR 96-001 WP, February.

Energy Daily. Selected issues 1991, 1992, and 1993. 
Fullerton, Don, Shaun P. McDermott, and Jonathan P. Caulkins (1996). "Sulfur Dioxide Compliance of a Regulated Utility." Cambridge: National Bureau of Economic Research, Working Paper 5542, April.

Hausker, Karl (1992). “The Politics and Economics of Auction Design in the Market for Sulfur Dioxide Pollution." Journal of Policy Analysis and Management, 11 (Fall): 553-572.

Hoske, Mark T. (1993). "SO2 Allowance Cost Falls to \$122/ton in First EPA Auction" Electric Power and Light, 71(5), p1.

ICF Resources Incorporated (ICF, 1990). "Comparison of the Economic Impacts of the Acid Rain Provisions of the Senate Bill (S. 1630) and the House Bill (S. 1630)." Draft Report Prepared for the U.S. Environmental Protection Agency, July.

Joskow, Paul L. and Richard Schmalensee (1996). "The Political Economy of Market-Based Environmental Policy: The U.S. Acid Rain Program." MIT Center for Energy and Environmental Policy Research, MIT-CEEPR 96-003 WP, March.

Laffont, Jean-Jacques (1995). "Game Theory and Empirical Economics: The Case of Auction Data." IDEI Document de Travail 55, Toulouse, December.

Rigdon, Joan E. (1992). “ALCOA Unit Arranges \$7.5 Million Sale of Pollution Allowances to Ohio Edison." Wall Street Journal. July 1. A6.

U.S. Environmental Protection Agency (EPA, 1995). Human Health Benefits from Sulfate Reductions Under Title IV of the 1990 Clean Air Act Amendments. Office of Air and Radiation, November.

U.S. Environmental Protection Agency (EPA, 1996). Acid Rain Program Update No. 3: Technology and Innovation. Acid Rain Division, EPA 430-R-96-004, May. 
Table 1

Allowances Sold In EPA Auctions And In The Private Market

\begin{tabular}{cccc}
\hline & $\begin{array}{c}\text { Number Allowances } \\
\text { Sold in EPA Auction }\end{array}$ & $\begin{array}{c}\text { Number of Allowances } \\
\text { Sold in the Private } \\
\text { Market }^{*}\end{array}$ & $\begin{array}{c}\text { Total } \\
\text { Allowances } \\
\text { Sold }\end{array}$ \\
\hline Through March 1993 & 150,010 & 130,000 & 280,010 \\
April 1993-March 1994 & 176,200 & 226,384 & 402,584 \\
April 1994-March 1995 & 176,400 & $1,466,996$ & $1,643,396$ \\
April 1995-March 1996 & 275,000 & $4,917,560$ & $5,292,560$ \\
Total: & 777,610 & & $7,518,550$ \\
\hline
\end{tabular}

\footnotetext{
* The number of allowances sold in the private market includes inter-utility trades, trades between utilities and third parties, and trades between two non-utility parties. This number excludes intra-utility trades (including intra-holding company trades), reallocations, and options to trade which have not been exercised.
} 
Table 2

Percentage Differences Between Average Winning Bids and Lowest Winning Bids in EPA Auctions

\begin{tabular}{cccc}
\hline Year & Spot Auction & $\begin{array}{c}\text { 6-Year Advance } \\
\text { Auction }\end{array}$ & $\begin{array}{c}\text { 7-Year Advance } \\
\text { Auction }\end{array}$ \\
\hline 1993 & 20.6 & - & 11.5 \\
1994 & 6.0 & 5.7 & 6.4 \\
1995 & 1.5 & 2.3 & 1.6 \\
1996 & 3.2 & 1.9 & 1.9 \\
\hline
\end{tabular}


Table 3

Allowances Privately Offered For Sale In EPA Auctions

\begin{tabular}{cccccc}
\hline Year & $\begin{array}{c}\text { Allowances } \\
\text { Offered }\end{array}$ & $\begin{array}{c}\text { Allowances } \\
\text { Offered } \\
\text { That Sold }\end{array}$ & $\begin{array}{c}\text { Percentage } \\
\text { Offered } \\
\text { That Sold }\end{array}$ & $\begin{array}{c}\text { Total } \\
\text { Allowances } \\
\text { Sold }\end{array}$ & $\begin{array}{c}\text { Percentage of } \\
\text { Total Sales } \\
\text { Offered }\end{array}$ \\
\hline 1993 & 125,510 & 10 & 0.01 & 150,010 & 0.01 \\
1994 & 155,001 & 1,200 & 0.77 & 176,200 & 0.68 \\
1995 & 22,306 & 1,400 & 6.28 & 176,400 & 0.79 \\
1996 & 22,000 & 0 & 0.00 & 275,000 & 0.00 \\
& & & & & \\
Total: & 324,817 & 2,610 & 0.80 & 777,610 & 0.34 \\
\hline
\end{tabular}




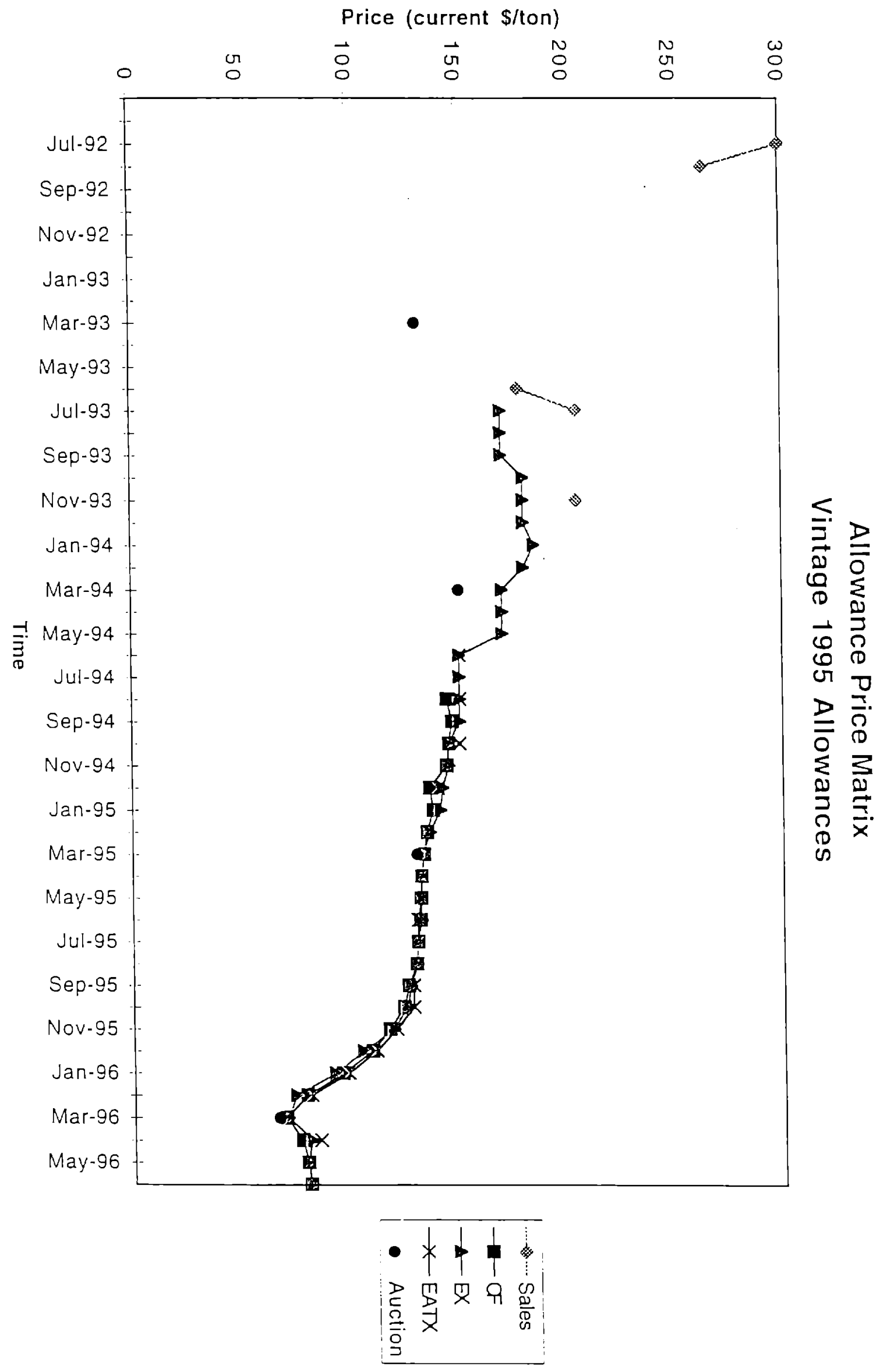




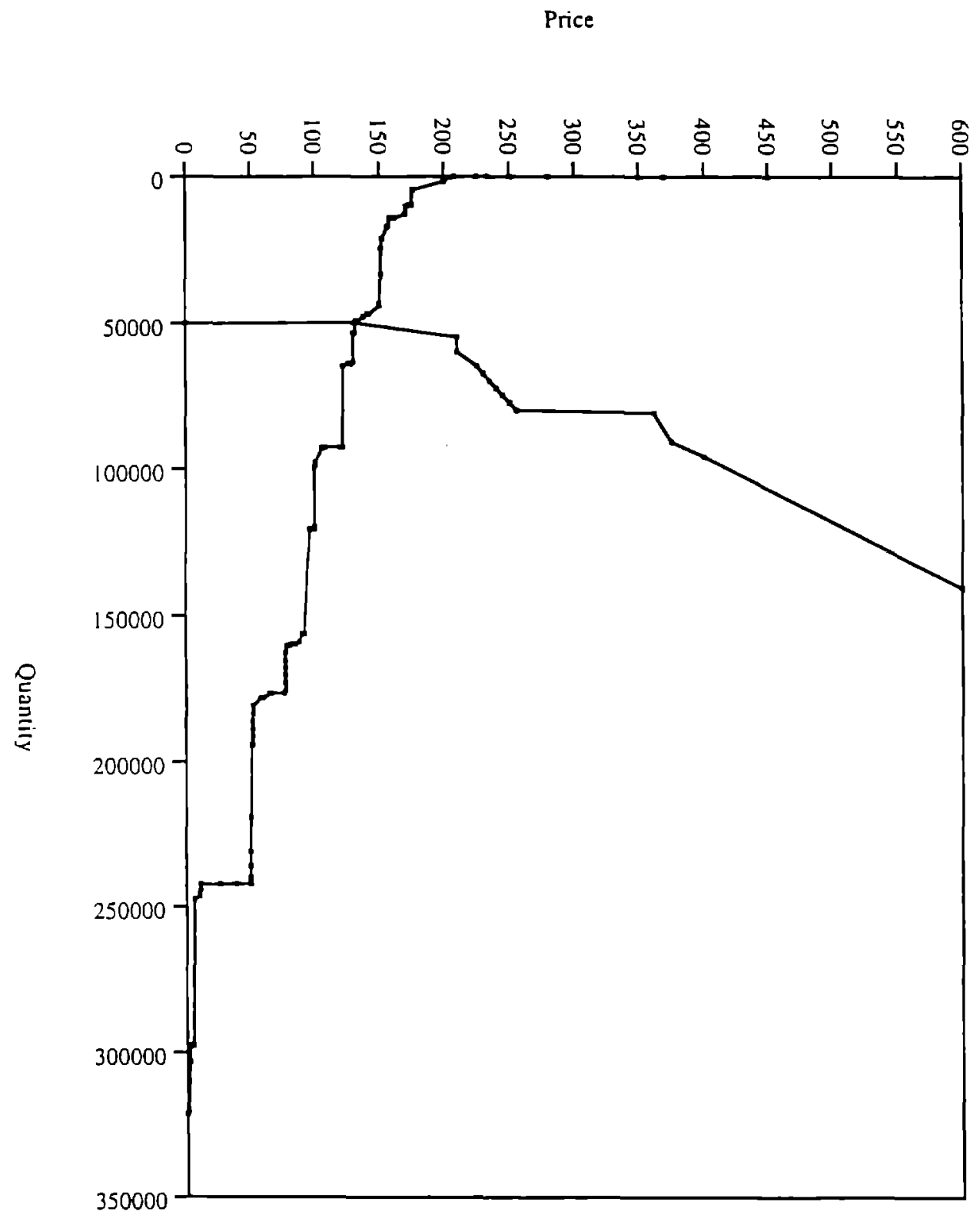

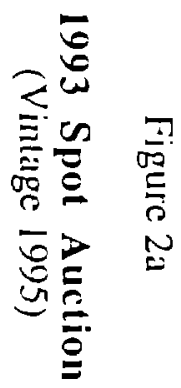

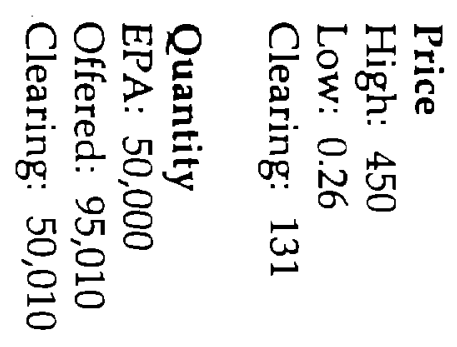


Price

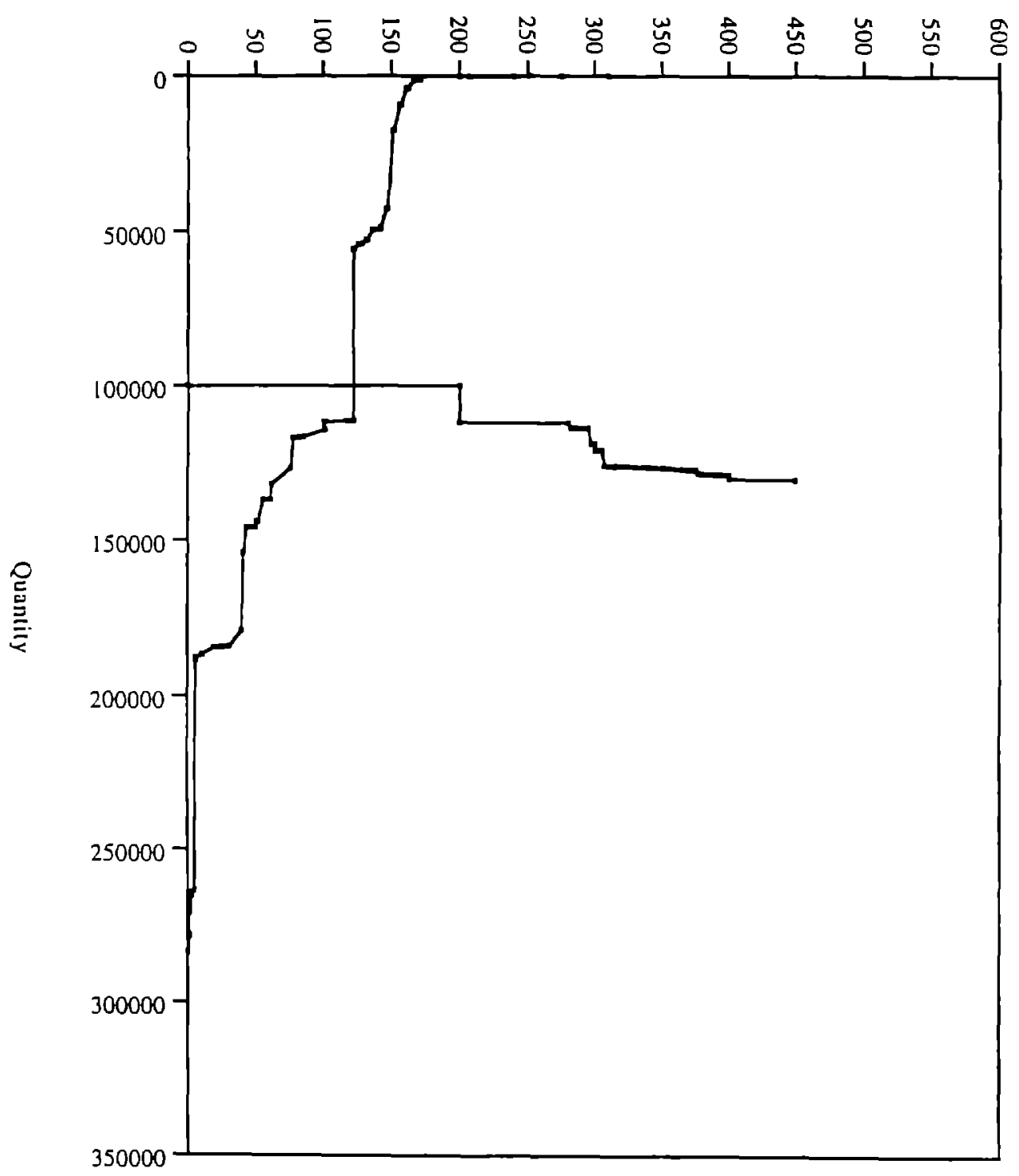

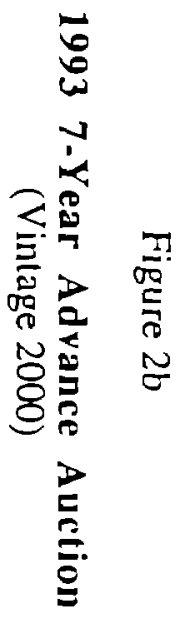

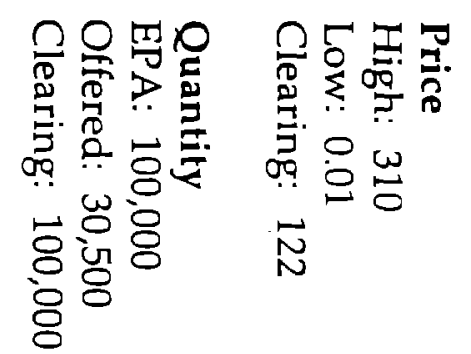




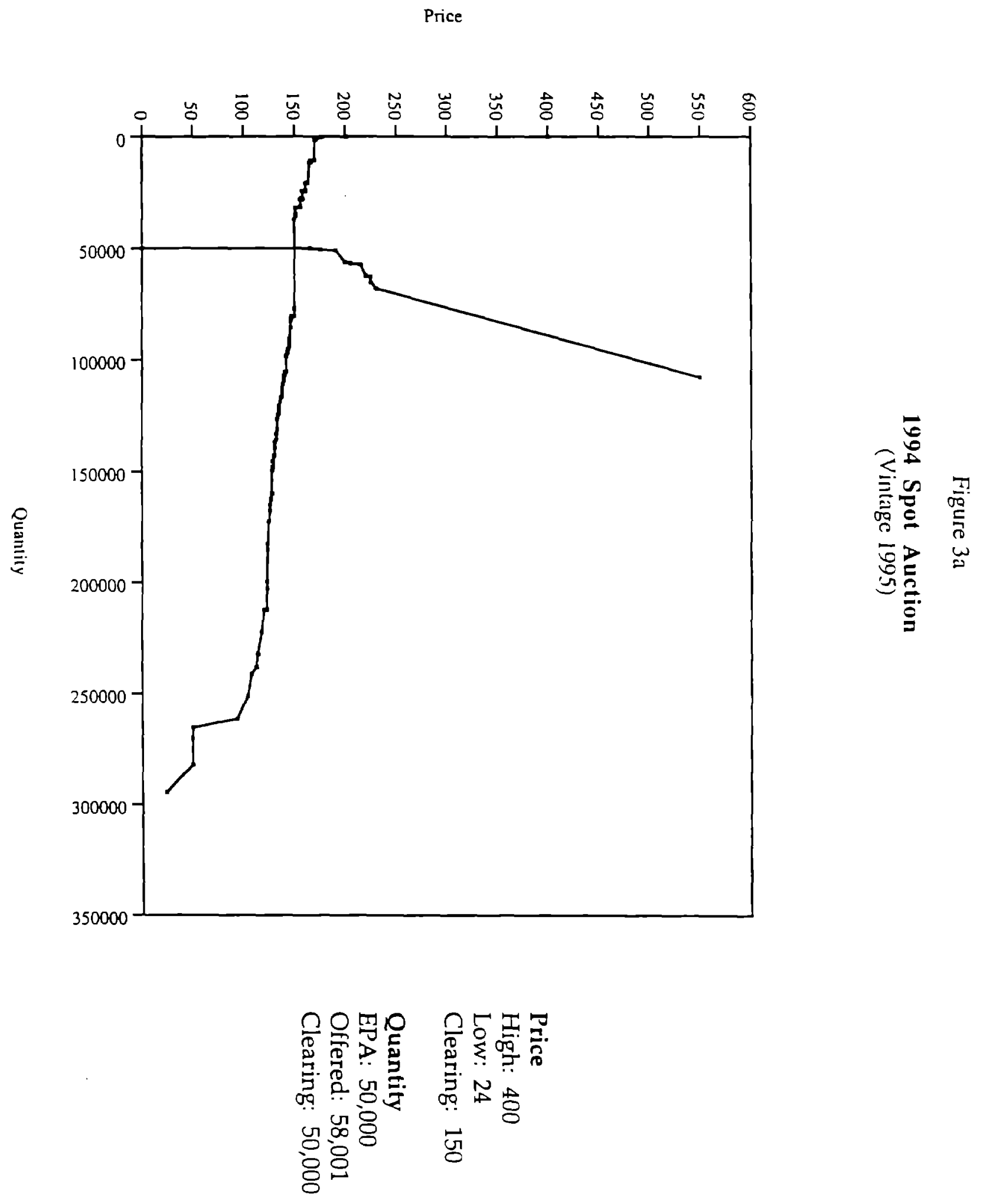




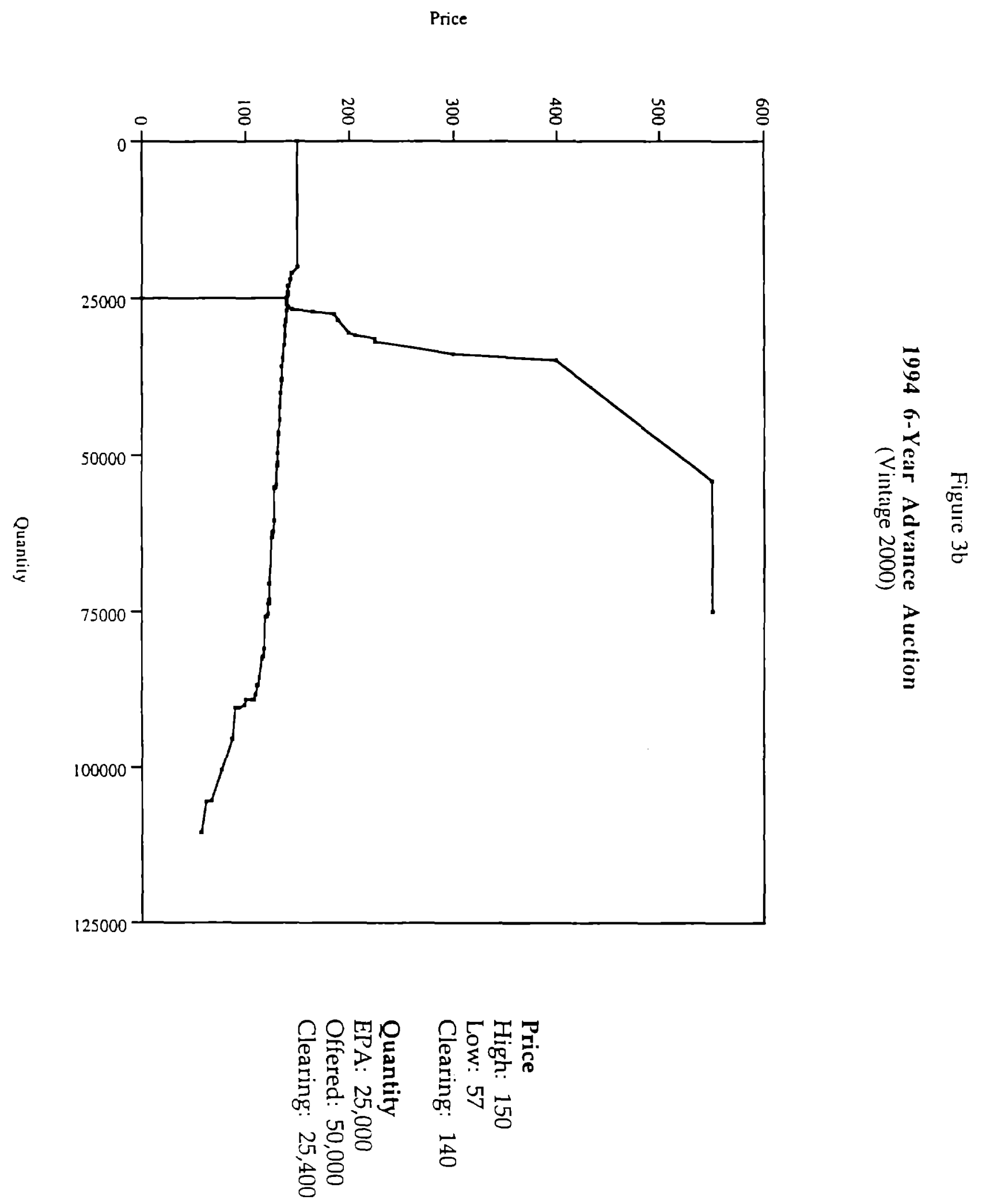


Price

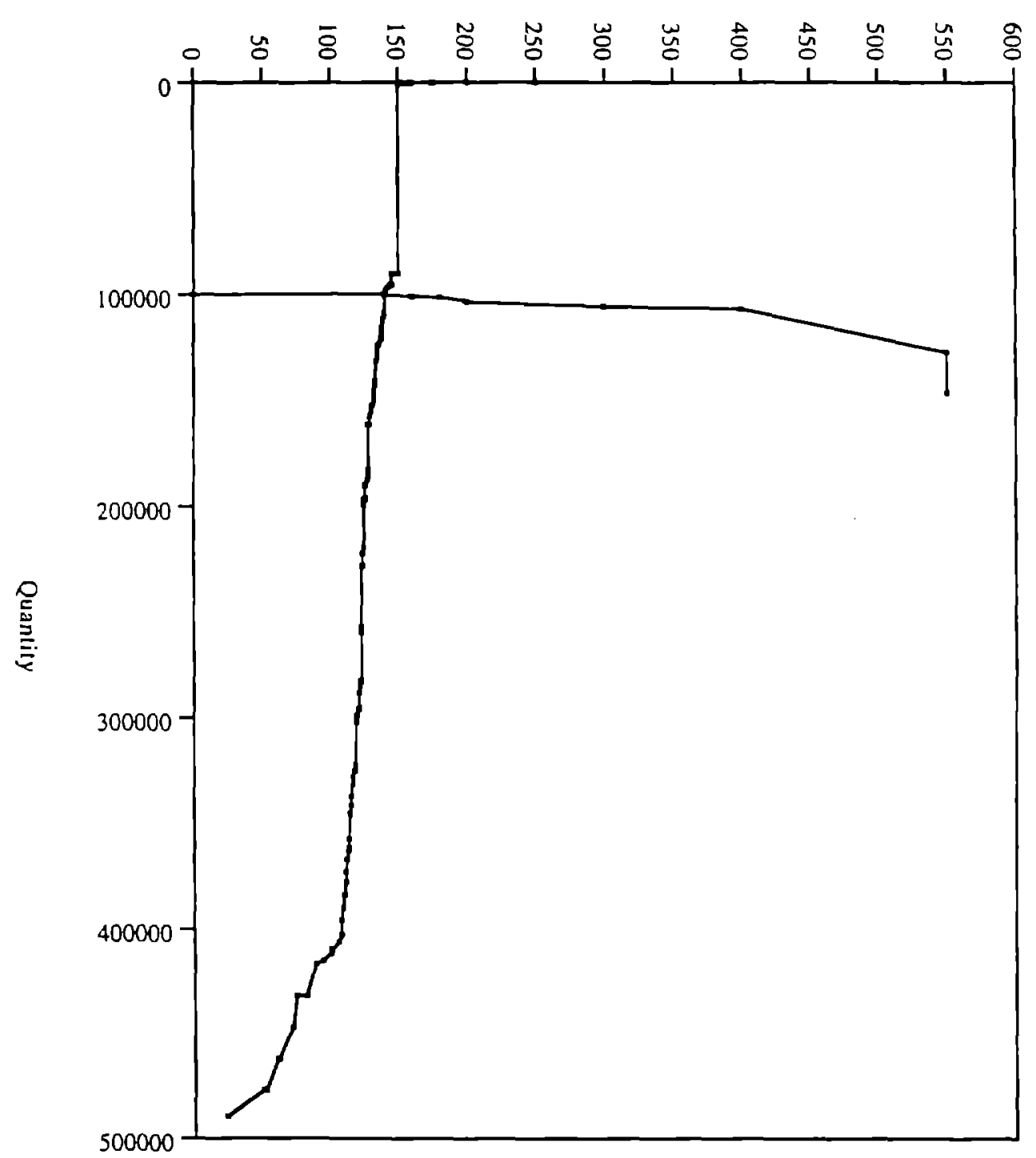

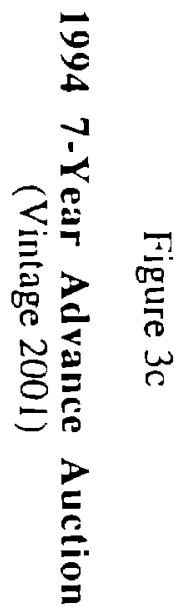

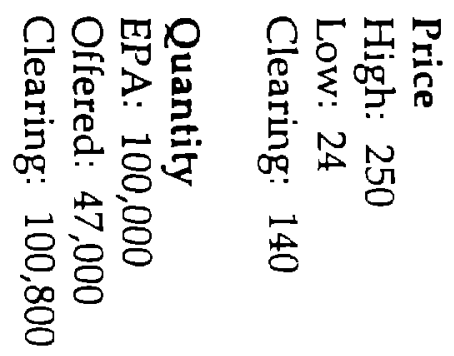


Price

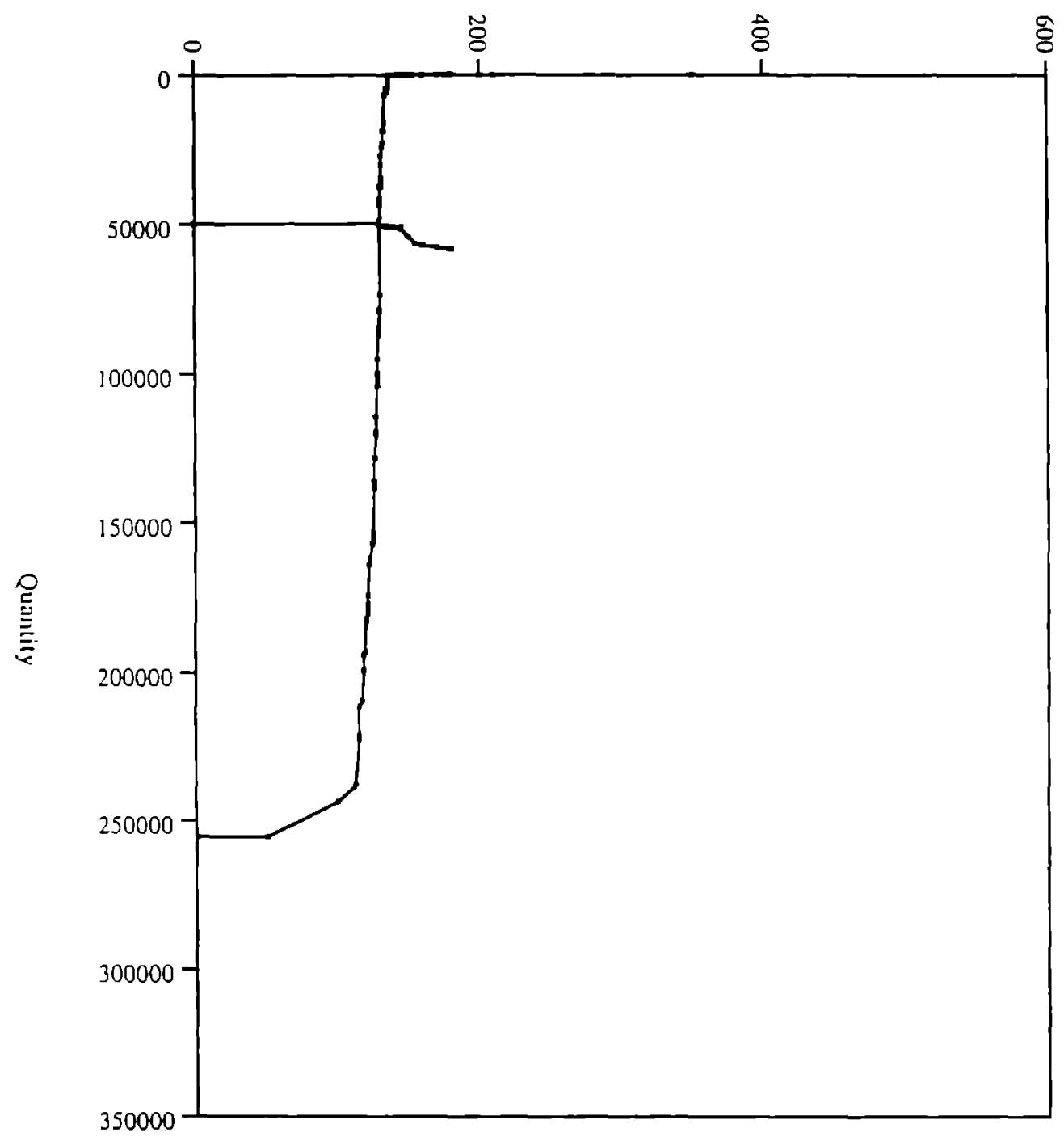

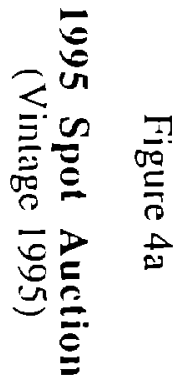

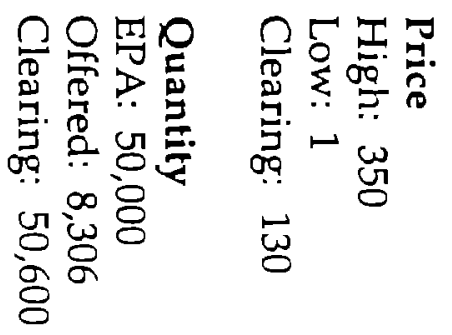


Price

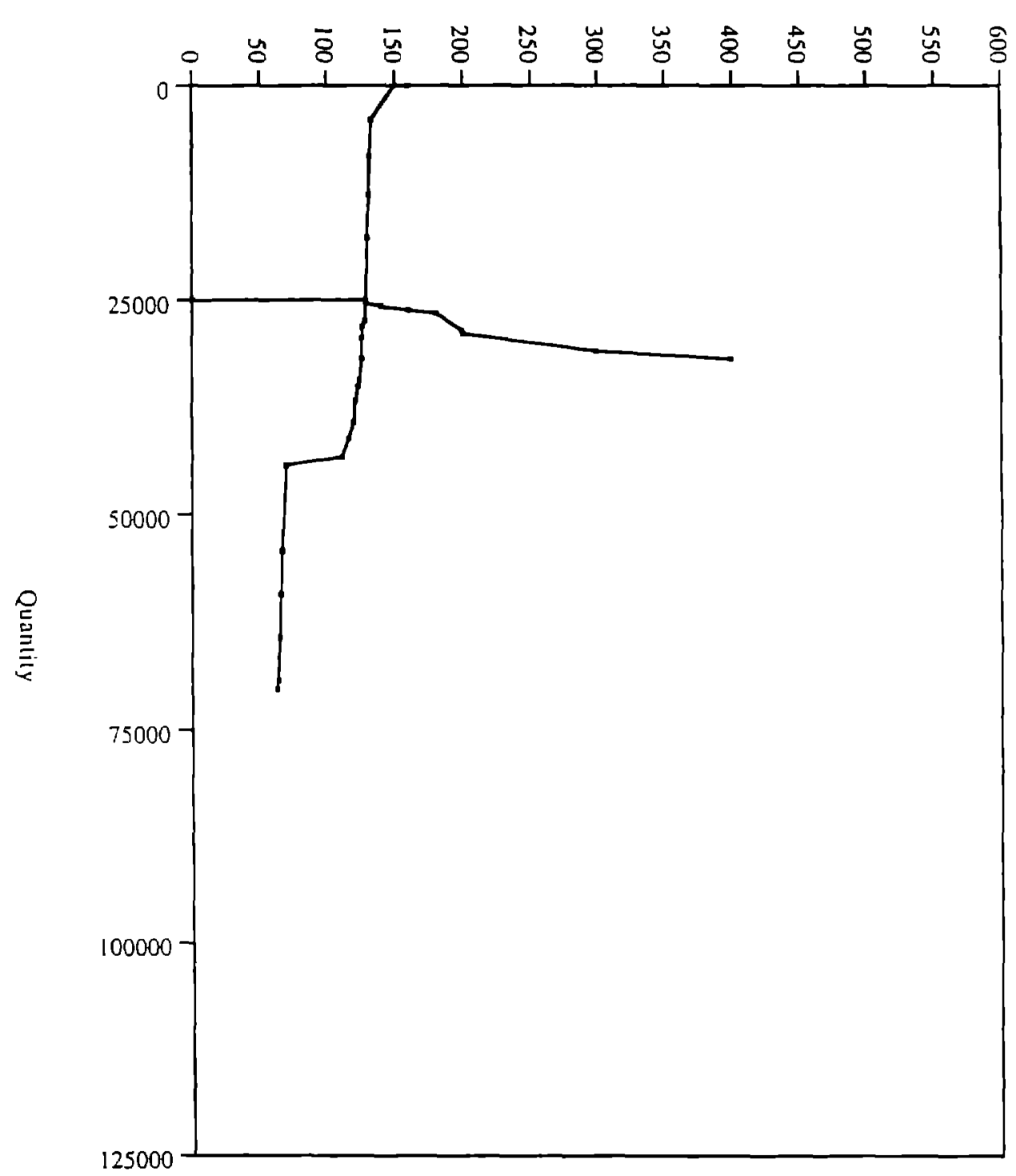

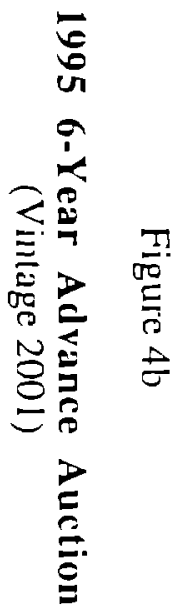

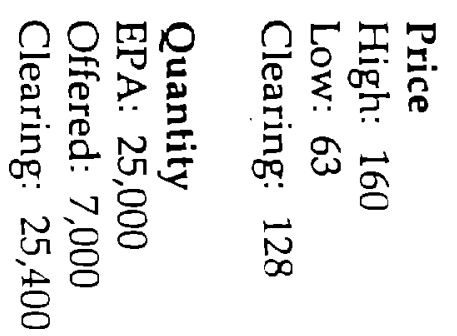




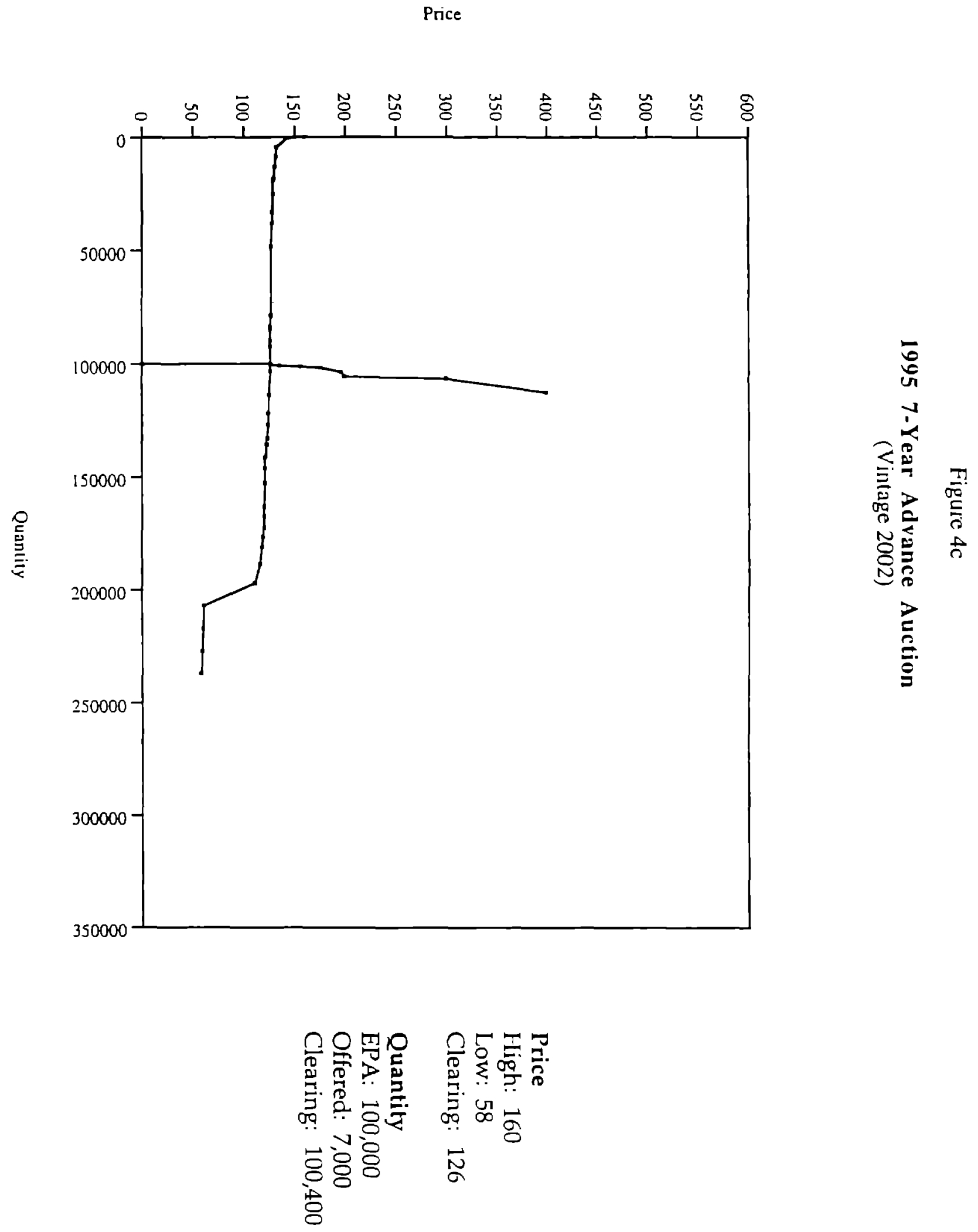


Price

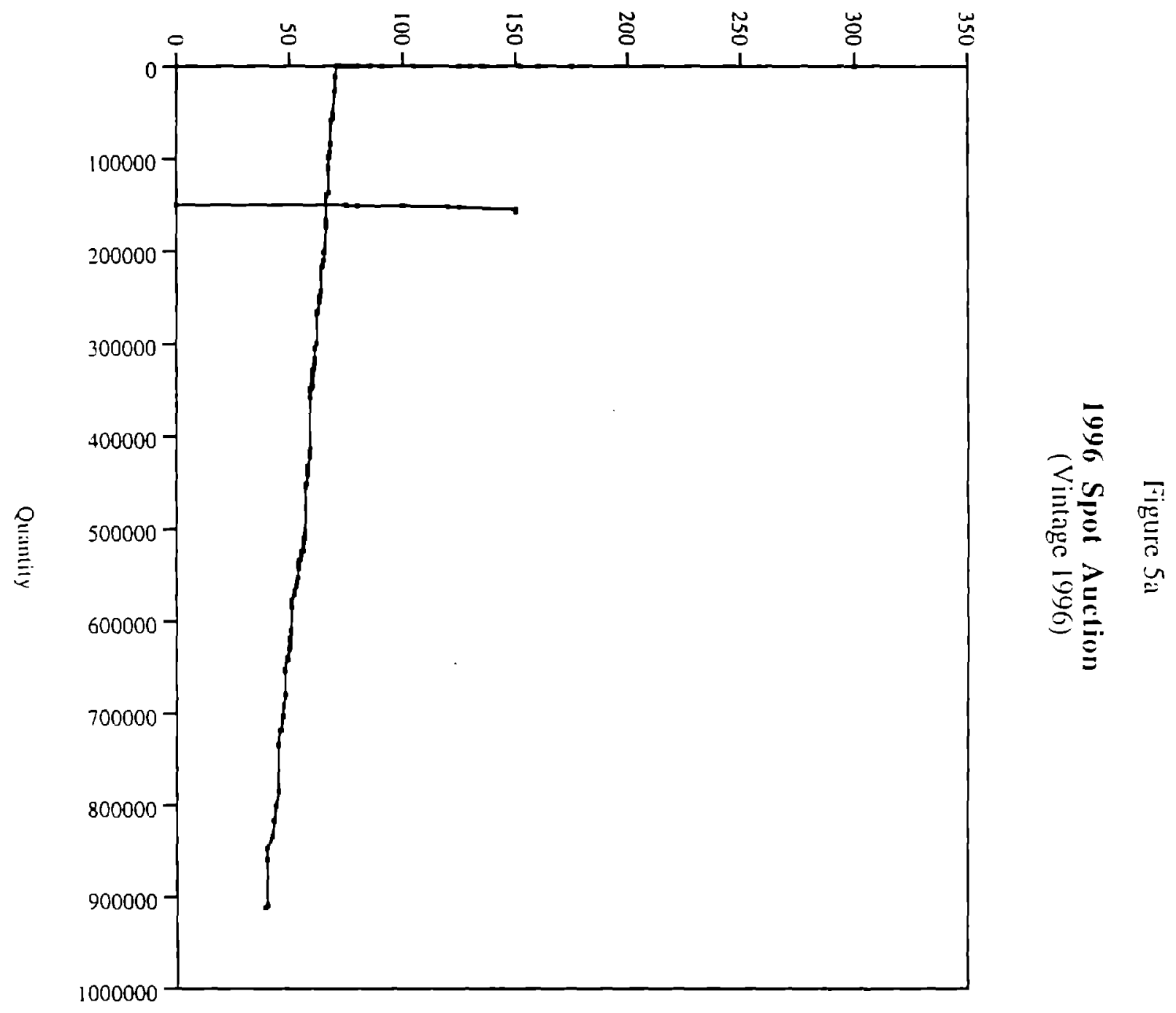

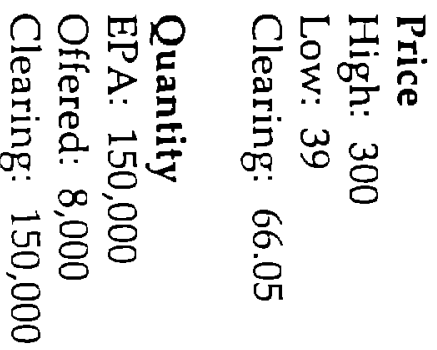


Price

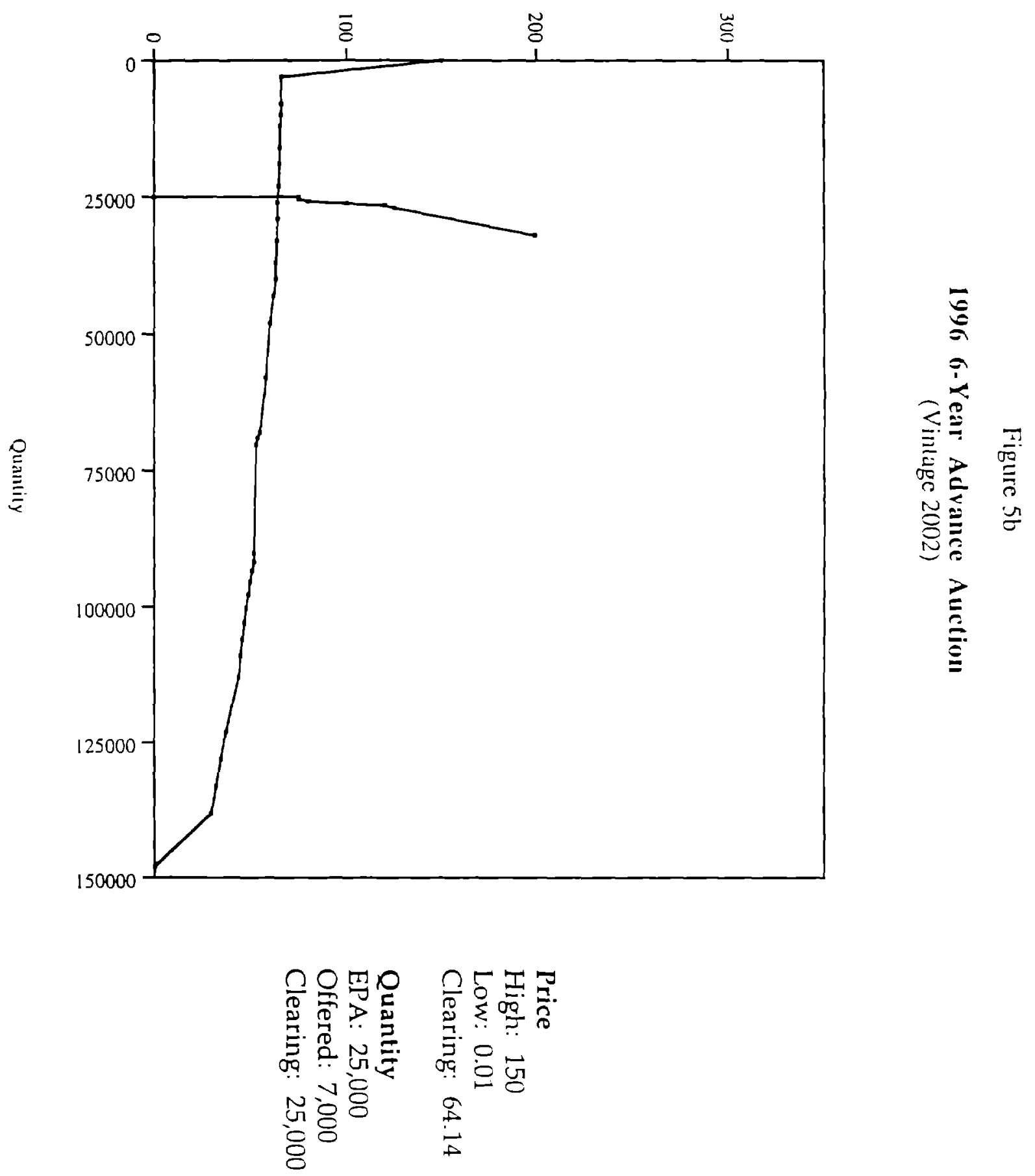



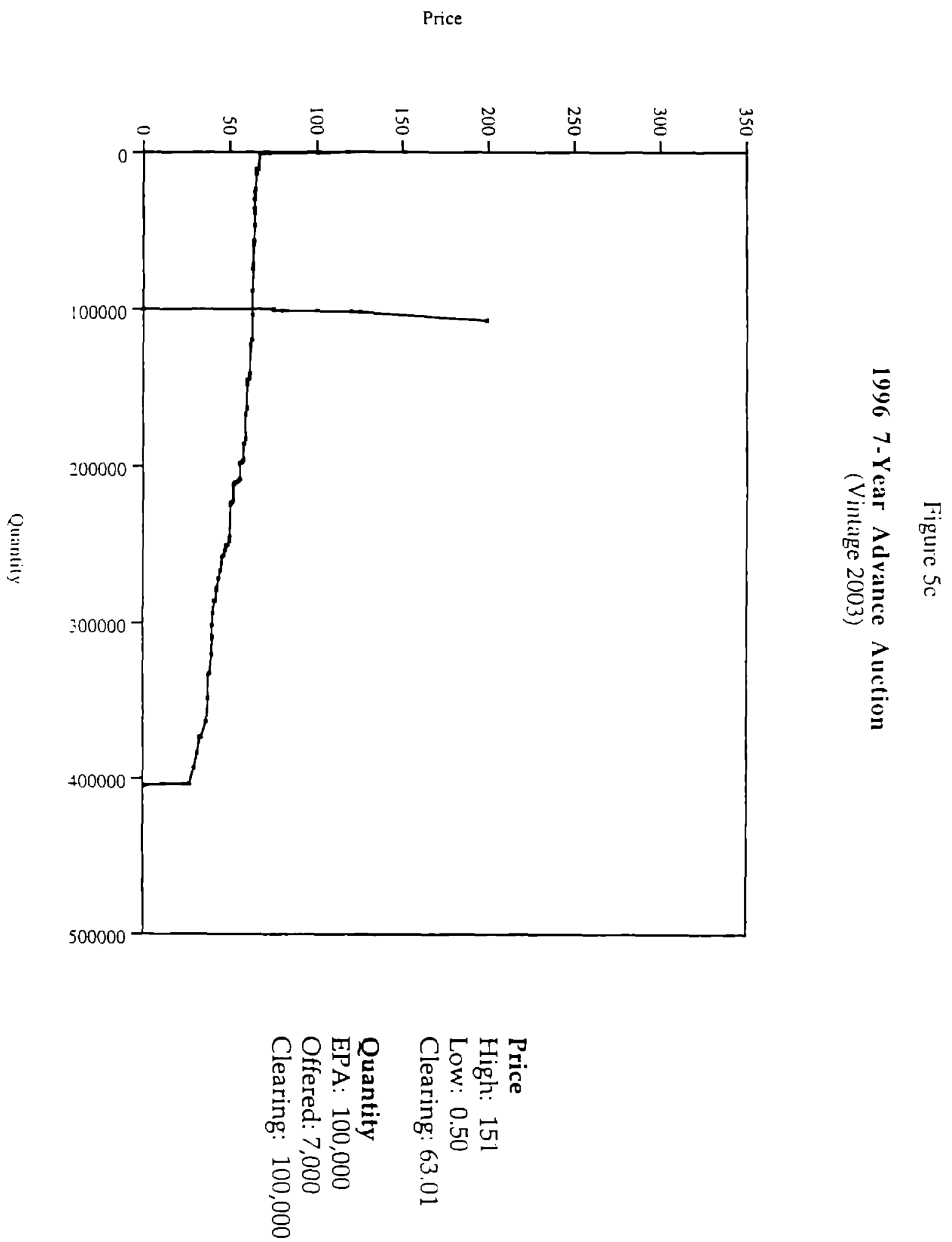